\title{
Optimalisasi radiografi gigi konvensional untuk membantu pemasangan implan gigi
}

\author{
Barunawaty Yunus \\ Bagian Radiologi \\ Fakultas Kedokteran Gigi Universitas Hasanuddin \\ Makassar, Indonesia
}

\begin{abstract}
Radiography as diagnostic tool is essential for treatment plan of implant. Many techniques used to produce radiography are recommended to support the dentist in accessing area of implantation. Many implant experts use panoramic radiography as guidelines of jaw bone evaluation as recommended by implant procedures. In order to get optimal measurement, occlusal radiography technique can be added to evaluate the bone thickness.panoramic and periapical radiography can solely evaluate the width and height of jaw bone. This study proposed to evaluate parametric value, as width, height, and thickness of jaw bone by conventional dental diagnostic radiography. This was observational study, with cross sectional design. Samples were chosen as population target that fulfilled samples criteria. Number of samples were 30 and and analyzed using the SPSS program for Windows 14.0 and T-test. In this study, it can be concluded that there was significant difference before and after conversion of all parametric radiography conventional tooth on jaw bone.
\end{abstract}

Keywords: conventional dental radiography, dental implant, optimalized diagnostic radiography.

\begin{abstract}
ABSTRAK
Gambaran radiografi sebagai alat bantu diagnostik merupakan komponen esensial dalam perencanaan perawatan menggunakan implan. Banyak temuan dalam membuat gambaran radiografi yang direkomendasikan untuk membantu para dokter gigi dalam mengakses daerah sasaran pemasangan implan. Banyak praktisi implan menggunakan radiografi panoramik sebagai pedoman evaluasi tulang rahang berdasarkan rekomendasi produsen implan. Namun untuk mendapatkan hasil pengukuran yang optimal, maka dapat ditambahkan suatu teknik radiografi oklusal yang dapat melihat ketebalan tulang rahang. Hasil radiografi panoramik dan periapikal hanya dapat melihat lebar dan tinggi dari tulang rahang tersebut. Penelitian ini bertujuan untuk mendapatkan nilai parameter, yaitu lebar, tinggi, dan tebal tulang rahang dengan bantuan diagnostik radiografi gigi konvensional. Jenis penelitian ini adalah observasional dengan desain cross sectional. Sampel dipilih sesuai populasi target yang memenuhi kriteria sampel. Jumlah sampel sebanyak 30 orang sampai sampel terpenuhi. Data dianalisis dengan menggunakan program SPSS 14 for Windows dan uji-T. Dari hasil penelitian ini dapat disimpulkan bahwa ada perbedaan yang bermakna sebelum dan setelah konversi semua nilai parameter radiografi gigi konvensional.
\end{abstract}

Kata kunci: radiografi gigi konvensional, implan gigi, optimalisasi radiografi diagnostik.

Koresponden: Barunawaty Yunus, Bagian Radiologi, Fakultas Kedokteran Gigi Universitas Hasanuddin, Jl. Perintis Kemerdekaan Km.10, Talamanrea Makassar, Indonesia. 


\section{PENDAHULUAN}

Gambaran radiografi sebagai alat bantu diagnostik merupakan komponen esensial dalam perencanaan perawatan menggunakan implan. Banyak inovasi dilakukan dalam bidang radiografi untuk membantu para dokter gigi dalam mengakses daerah sasaran pemasangan implan. Walaupun penemuan dalam bidang teknologi telah menghasilkan inovasi baru bagi pemasangan implan gigi, radiografi gigi masih merupakan alat yang paling umum digunakan untuk mengukur kualitas dan kuantitas tulang rahang. ${ }^{1}$

Kebanyakan radiografi gigi dibuat pada film intraoral. Radiografi intraoral dibuat dengan meletakkan film di dalam mulut selama penyinaran. Radiografi intraoral yang digunakan pada relasi lebih dekat kepada obyek lebih detail dibanding dengan radiografi ekstraoral yang diambil di luar mulut dan tidak tumpang tindih dari bayangan. ${ }^{2}$

Radiografi yang dapat lebih luas menunjukkan jaringan mulut yang diinginkan dibanding yang dapat diperoleh dengan periapikal film adalah radiografi oklusal. Gambaran ini dibuat dengan menggunakan film oklusal. Film periapikal kadang-kadang digunakan untuk memperoleh gambaran oklusal pada anak-anak dan gambaran dari area yang sempit. ${ }^{2}$

Radiografi panoramik memberikan keterangan yang sangat berguna mengenai status gigi-geligi secara umum dan hubungan antara tulang alveolar, tulang basal dan struktur anatomis yang tidak memungkinkan pemasangan implan. Walaupun gambaran panoramik mengalami pembesaran, panjang dan jumlah implan yang akan dipasang pada daerah edentulus untuk mendukung gigitiruan tetap dapat diperkirakan. Radiografi periapikal intraoral dapat membantu dan sangat penting dalam memperkirakan dimensi mesiodistal daerah yang potensial untuk pemasangan implan dan untuk mendapatkan prakiraan awal mengenai dimensi vertikal. Suatu kombinasi antara gambaran panoramik dan intraoral seringkali direkomendasikan untuk evaluasi awal daerah sasaran pemasangan implan. ${ }^{1}$

Radiografi panoramik banyak digunakan pada diagnosis dari penyakit dan abnormalitas. Beberapa penggunaan radiografi panoramik, misalnya survei lengkap dapat dibuat pada gigi geligi dan struktur yang berhubungan, beberapa tumor dan kista-kista dapat diperiksa dan dievaluasi, lokasi dan posisi dari gigi-gigi yang impaksi dapat ditentukan, fraktur-fraktur wajah bagian bawah dapat dilokasikan, dan pola-pola pertumbuhan rahang dapat diteliti dan dievaluasi. Kegunaan ini membuan radiografi panoramik merupakan suatu hasil pemeriksaan yang berharga dalam membantu mendiagnosis antara lain gigigeligi, tulang rahang, sendi temporomandibula, struktur-struktur yang ada di dekatnya, menemukan diagnosis kehilangan tulang alveolar, gigi, dan lesi tulang, mengetahui letak fraktur pada wajah bagian bawah, mengetahui letak gigi impaksi, evaluasi tumor dan kista, serta mempelajari dan mengevaluasi perkembangan gigi dan tulang rahang. ${ }^{2-4}$

Dari keterangan di atas, dapat diketahui bahwa radiografi panoramik memberikan gambaran keseluruhan regio maksilomandibular dalam satu film, dapat mengurangi waktu, memerlukan sedikit keahlian ahli radiologi oral dan maksilofasial, dan tidak memberikan hal yang tidak menyenangkan bagi pasien. Akan tetapi, disamping hal-hal positifnya, harus tetap diingat, oleh karena magnifikasi, kurangnya definisi dan struktur yang tumpang tindih, radiografi panoramik mungkin kualitas diagnosisnya lebih rendah dibandingkan radiografi intraoral. $^{3}$ 
Perawatan kehilangan gigi dapat dilakukan dengan berbagai cara. Sejalan dengan semakin berkembangnya teknologi kedokteran gigi, perawatan kehilangan gigi yang makin populer saat ini adalah perawatan dengan implan gigi. Perawatan ini merupakan salah satu perawatan alternatif kehilangan gigi yang dapat mengatasi berbagai masalah keterbatasan gigitiruan konvensional. ${ }^{5-7}$

Disamping berbagai keunggulannya dibandingkan perawatan gigitiruan konvensional, biaya perawatan implan gigi di Indonesia saat ini relatif mahal, dan prosedurnya memerlukan pembedahan yang relatif lebih kompleks. Penempatan implan ke dalam rahang juga berisiko menyebabkan terjadinya kerusakan struktur anatomis seperti kanalis mandibula dan sinus maksilaris. Risiko yang dapat menyebabkan kegagalan perawatan implan gigi tersebut harus diantisipasi dengan melakukan rencana perawatan yang efisien dan akurat. $^{8,9}$

Salah satu faktor penting yang berperan dalam keberhasilan perawatan implan gigi adalah akurasi evaluasi kualitas dan kuantitas tulang rahang. Parameter kualitas dan kuantitas tulang rahang yang akan menerima implan tersebut, berupa informasi diagnostik gambaran tulang dalam tiga dimensi objek, yaitu tebal, tinggi, dan densitas tulang rahang. Untuk memperoleh informasi tersebut diperlukan teknologi digital guna mendapatkan parameter tulang rahang yang relatif akurat. $^{6,10,11}$

Implan telah digunakan secara luas untuk menggantikan elemen gigi yang hilang. Hal tersebut menunjukkan salah satu kemajuan penting dalam rehabilitasi oral. Meskipun demikian, evaluasi ketat terhadap kualitas dan kuantitas tulang yang masih ada dan lokasi struktur anatomis yang akurat perlu dilakukan untuk menjamin kesuksesan perawatan dengan implan. $^{12}$

Implan gigi adalah suatu piranti yang ditanam secara bedah ke dalam jaringan lunak atau ke dalam tulang rahang agar gigitiruan dapat dipasang di atasnya. Piranti ini terdiri atas dua bagian, yaitu bagian struktur supra dan bagian struktur infra. Bagian infra tertanam dalam tulang rahang dan berfungsi sebagai kaitan, sementara bagian atas sebagai tempat gigitiruan dipasang. ${ }^{13}$

Implan gigi adalah teknik mengganti gigi yang hilang yang semakin populer saat ini karena seperti gigi yang muncul dari dalam tulang rahang, sama dengan gigi asli. Hal ini menyebabkan masalah perbedaan tekanan jaringan pendukung hampir tidak ada. Salah satu kekurangan implan gigi adalah harganya yang relatif mahal dan pembuatannya membutuhkan keterampilan khusus dari operator. ${ }^{13}$

Implan gigi merupakan suatu gigi buatan atau pengganti akar, dan digunakan dalam bidang kedokteran gigi prostodonsia untuk mendukung gigitiruan. ${ }^{14}$ Implan gigi merupakan suatu pengganti gigi yang sangat ideal saat ini, karena sifatnya serta bentuknya yang menyerupai gigi alami. Implan gigi terbuat dari logam titanium yang bersifat biokompatibel. ${ }^{15}$

Berbagai perangkat pencitraan radiografi diagnostik modern sudah digunakan untuk perawatan implan gigi, namun di Indonesia khususnya Makassar, ketersediaan pemeriksaan radiografik modern ini masih sangat terbatas. Banyak dokter gigi praktisi implan yang hanya menggunakan radiograf panoramik sebagai pedoman evaluasi tulang rahang, berdasarkan rekomendasi produsen implan. Dari survei radiografis hasil perawatan implan gigi pada 18 praktisi implan di Jakarta, 44,44\% melakukan 
pembuatan radiograf periapikal, 94,44\% panoramik, dan hanya 38,89\% yang menggunakan radiograf periapikal dan panoramik. Dari 109 kasus perawatan implan hasil survei tersebut diperoleh 22 kasus $(22,18 \%)$ mengalami kerusakan tulang lebih dari 50\%. Belum adanya laporan resmi mengenai keberhasilan perawatan implan gigi di Indonesia, memungkinkan kenyataan bahwa angka ini sebenarnya bisa jauh lebih tinggi lagi. ${ }^{16}$ Kegagalan perawatan implan gigi tidak hanya menyebabkan kerugian finansial, melainkan juga mempengaruhi kondisi tulang rahang pasien selanjutnya, bahkan secara psikologis dapat berdampak buruk pada pasien. Di negara maju tingkat kegagalan yang terjadi dilaporkan mencapai $20 \%$. $^{7,8,17-20}$

Akan tetapi, bagaimana cara mengoptimalkan radiografi gigi konvensional untuk mendapatkan parameter yang tepat dalam pemasangan implan? Melihat fakta-fakta tersebut di atas, diperlukan upaya untuk mengoptimalkan atau meningkatkan mutu informasi diagnostik radiografi gigi konvensional, baik kualitas maupun kuantitas dari tulang rahang pada perawatan implan gigi. Hal ini dapat tercapai dengan menggunakan alat bantu radiografi diagnostik, yaitu radiografi gigi konvensional, antara lain adalah radiografi panoramik, radiografi periapikal. Selain itu juga diperlukan suatu tambahan teknik radiografi yaitu radiografi oklusal, sehingga dapat menghasilkan nilai parameter dari lebar, tinggi, dan tebal tulang rahang. Nilai parameter tersebut yang kemudian akan dikonversi untuk mendapatkan nilai parameter yang lebih akurat, sehingga sangat membantu dalam pemasangan implan gigi.

Artikel ini bertujuan untuk melaporkan hasil penelitian mengenai nilai parameter tulang rahang yang lebih akurat dalam mengukur lebar, tinggi, dan tebalnya dengan mengkonversi nilai parameter pada radiografi gigi konvensional untuk pemasangan implan gigi sehingga nantinya dapat memudahkan para praktisi implan untuk mendapatkan ukuran yang tepat dan akurat dari parameter tulang rahang dalam pemasangan implan gigi, agar dapat mengurangi kesalahan dan kegagalan pada pemasangan implan.

\section{BAHAN DAN METODE}

Penelitian ini adalah penelitian yang bersifat observasional dengan pendekatan cross sectional. Subjek perlakuan adalah manusia sebanyak 30 orang dengan kriteria kehilangan satu atau lebih gigi, umur 20-50 tahun, dan mempunyai densitas tulang yang baik. Alat yang digunakan adalah pesawat radiografi ekstraoral dan pesawat radiografi intraoral dengan menggunakan teknik radiografi panoramik, teknik radiografi periapikal dan teknik radiografi oklusal. Film yang digunakan adalah film intraoral berukuran $3 \times 4 \mathrm{~cm}$, film oklusal berukuran $5,7 \times 7,5 \mathrm{~cm}$ dan film panoramik berukuran $15 \times 30 \mathrm{~cm}$. Sebuah bola logam berukuran $6 \mathrm{~mm}$ digunakan untuk konversi hasil foto dari foto panoramik, periapikal dan oklusal. Penelitian dilaksanakan di Rumah Sakit Pendidikan Gigi dan Mulut (RSGM) FKG Unhas, pada bulan Desember 2008 sampai Januari 2009 hingga jumlah sampel minimal terpenuhi.

Data kemudian dianalisis secara statistik menggunakan program SPSS versi 14.0 untuk Windows. Data kemudian diuji dengan menggunakan uji-T untuk mendapatkan tingkat keakurasian tiap pengukuran parameter dari lebar, tinggi dan tebal tulang rahang sebelum dan setelah konversi, dengan menggunakan foto panoramik, foto periapikal dan foto oklusal pada pemasangan implan gigi. 


\section{HASIL PENELITIAN}

Tabel 1. Hasil foto panoramik pada pemeriksaan 30 orang sampel

\begin{tabular}{cccc}
\hline \multirow{2}{*}{ Ukuran } & \multicolumn{2}{c}{ Mean $(\mathrm{mm})$} & \multirow{2}{*}{ Kebermaknaan } \\
\cline { 2 - 3 } & Sebelum konversi & Setelah konversi & \\
\hline Lebar & 11,59 & 10,28 & $0,000^{* * *}(\mathrm{p}<0,05)$ \\
Panjang & 13,57 & 11,77 & $0,000^{* * *}(\mathrm{p}<0,05)$ \\
\hline
\end{tabular}

Tabel 2. Hasil foto periapikal pada pemeriksaan 30 orang sampel

\begin{tabular}{cccc}
\hline \multirow{2}{*}{ Ukuran } & \multicolumn{2}{c}{ Mean $(\mathrm{mm})$} & \multirow{2}{*}{ Kebermaknaan } \\
\cline { 2 - 3 } & Sebelum konversi & Setelah konversi & \\
\hline Lebar & 10,57 & 9,86 & $0,000^{* * *}(\mathrm{p}<0,05)$ \\
Panjang & 11,31 & 10,62 & $0,000^{* * *}(\mathrm{p}<0,05)$ \\
\hline
\end{tabular}

Tabel 3. Hasil foto oklusal pada pemeriksaan 30 orang sampel

\begin{tabular}{cccc}
\hline \multirow{2}{*}{ Ukuran } & \multicolumn{2}{c}{ Mean $(\mathrm{mm})$} & \multirow{2}{*}{ Kebermaknaan } \\
\cline { 2 - 3 } & Sebelum konversi & Setelah konversi & \\
\hline Tebal & 7,47 & 7,31 & $0,002 * * *(\mathrm{p}<0,05)$ \\
\hline
\end{tabular}

Pada tabel 1, 2, dan 3 didapatkan hasil dengan uji $\mathrm{T}$ yang signifikan, yaitu nilai $\mathrm{p}<0,05$ pada teknik foto panoramik dalam ukuran lebar dan panjang, foto periapikal dalam ukuran lebar dan panjang, dan foto oklusal dalam ukuran tebal sebelum dan setelah konversi.

Dari ketiga teknik foto yang dilakukan tersebut di atas didapatkan bahwa teknik foto oklusal dalam ukuran tebal merupakan teknik foto yang paling mendekati nilai konversi dengan nilai rata-rata parameter $0,16 \mathrm{~mm}$, kemudian teknik foto periapikal dalam ukuran panjang dengan nilai rata-rata parameter $0,69 \mathrm{~mm}$, foto periapikal dalam ukuran lebar dengan nilai rata-rata parameter $0,71 \mathrm{~mm}$, foto panoramik dalam ukuran lebar dengan nilai rata-rata parameter 1,31 $\mathrm{mm}$, dan yang paling terakhir adalah foto panoramik dalam ukuran panjang dengan nilai rata-rata parameter $1,8 \mathrm{~mm}$.

\section{DISKUSI}

Pada tabel 1 terlihat adanya perbedaan nilai parameter sebelum dan setelah konversi pada teknik radiografi panoramik baik dalam ukuran lebar maupun ukuran panjangnya. Hal ini terjadi karena teknik radiografi panoramik mempunyai pembesaran gambar dari aslinya. Distorsi pada radiografi panoramik tidak dapat dihindari karena sorotan pada film, tetapi berhubungan dengan proyeksi struktur yang bervariasi pada beberapa individu dan antar individu itu sendiri. Perbedaan bentuk serta ukuran tulang rahang dan gigi, variasi susunan gigi pada rahang dan asimetri antara sisi kanan dan kiri, semua itu menyebabkan terjadinya perbedaan derajat distorsi. ${ }^{21}$ Radiografi panoramik dianggap hanya sebagai pelengkap dari suatu pemeriksaan, bukan sebagai pengganti radiografi periapikal. Sebaiknya radiografi panoramik digunakan pada pemeriksaan tulang rahang yang luas, misalnya pada pasien yang edentulus, pasien yang tidak memerlukan prosedur radiografi intraoral dengan baik, atau pada pasien dengan gejala patologis yang luas. ${ }^{22,23}$

Pada tabel 2 didapatkan adanya perbedaan nilai parameter sebelum dan setelah konversi pada teknik radiografi periapikal baik dalam ukuran 
lebar/mesiodistal maupun panjang/vertikal dari tulang rahang. Hal ini disebabkan karena pada radiografi periapikal mempunyai jarak antara film dan sinar-X adalah 16 inci dan posisi film dan sumber sinar diatur sedemikian rupa agar tegak lurus, walaupun radiografi periapikal dengan teknik paralel ini mempunyai ketajaman dan ketepatan yang cukup tinggi namun pembesaran gambar tidak dapat terelakkan. ${ }^{2,24}$

Pada tabel 3 didapatkan juga adanya perbedaan nilai parameter sebelum dan setelah konversi pada teknik radiografi oklusal dalam ukuran tebal atau bukolingual dari tulang rahang. Walaupun teknik radiografi oklusal merupakan pengukuran yang paling mendekati nilai konversi tetap masih mempunyai pembesaran. Hal ini disebabkan karena hanya bagian terlebar dari tulang rahang yang dapat diukur, yaitu bagian tepi bawah mandibula, sedangkan pada maksila teknik ini tidak dapat menggambarkan dengan baik karena keterbatasan anatomis. ${ }^{25}$

Dari hasil penelitian ini dapat disimpulkan bahwa ada perbedaan yang bermakna sebelum dan setelah konversi dari semua nilai parameter radiografi gigi konvensional pada tulang rahang. Dari ketiga teknik radiografi gigi konvensional yang digunakan terlihat bahwa yang paling mendekati nilai konversi adalah radiografi oklusal, kemudian radiografi periapikal dalam ukuran panjang kemudian lebarnya, selanjutnya radiografi panoramik dalam ukuran lebar dan yang paling besar dari nilai konversinya adalah ukuran panjangnya.

Mengingat pentingnya penelitian ini, maka dapat disarankan kapada para praktisi implan yang akan melakukan perawatan implan gigi hendaknya melakukan pemeriksaan diagnostik lengkap yaitu pemeriksaan radiografi panoramik, periapikal dan oklusal yang telah dikonversi, sehingga praktisi implan dapat menghindarkan diri dari kegagalan pemasangan implan.

\section{DAFTAR PUSTAKA}

1. Anil S. A Method of gauging dental radiographs during treatment planning for dental impalnts. J Contemp Dent Prac 2007; 8 (6): 1-3

2. Fundament of dental radiology. [serial online] 2006; [1 screen]; Available from: http://www.waybuilder.net/sweethaven/MedT ech/Dental/DentalRad/html. Accesed: September 21, 2008

3. Lee JS, Kang BC. Screening panoramic radiographs in a group of patients visiting a health promotion center. Korean J Oral Maxillofac Radiol 2005; 35: 199-202.

4. Kantor ML, Slome BA. Efficacy of panoramic radiography in dental diagnosis and treatment planning. Available from: http://jdr.iadjournals.org/cgi/html. Accesed: September 21, 2008.

5. Block M, Kent J, Guerra L. Implants in dentistry: Essential of endosseous implant for maxillofacial reconstruction. Philadelphia: WB Saunders Company; 1997. p.74-147.

6. Misch CE. Contemporary impant dentisrty. 2nd ed. St. Louis: Mosby; 1999. p.73-118.

7. Elsubehi ES, Attard N, Zarb GA. Implant prosthodontics for edentulous patients: currents and future directions. In: Zarb GA, Bolender CL, editors. Prosthodontic treatment for edentulous patiens complete dentures and implant-supported protheses. $12^{\text {th }}$ ed. St Louis: Mosby; 2004. p.528-38.

8. Nevins M, Mellonig JT. Implant therapy clinical approach and evidence of success. Illinois: Quintessence; 1998.

9. Niedermeier W. Dental implan failure and allergic reaction IADR implant prosthodontic \& materials. Brisbane; 2006.

10. White SC, Pharaoh MJ. Oral radiology principles and interpretation. $5^{\text {th }}$ ed. St. Louis: Mosby; 2004. p.71-209.

11. Mupparapu M, Sinner SR. Implant imaging for the dentist. J Can Dent Assoc 2004; 70(1):32. 
12. Dantas JA, Fhilo AM, Campos PSF. Computed tomography for dental implants: the influence of the gantry angle and mandibular positioning on the bone height and width. Dentomaxillofac Radiol 2005; 34: 2.

13. Sulle HH, Machmud E. Restorasi implan sistem bone-lock. J Medika Nusantara 2004; 5(1). Available from http://med.unhas.ac. id/index2.php?option=com_content\&do_pdf= 1\&id=151. Accesed October 10, 2008.

14. Adipatria A, Mastuti I, Sejati IR. Kegagalan perawatan implan. Available from http://Images.bahasajiwa.multiplycom/attach ment/0/SEIJfgoKCoEAAEutSEc1/kegagalan \%20perawatan\%implan.ppt?nmid=98824365. Accesed October 10, 2008.

15. Implan dental. Available from http://drevyomfs.blogspot.com/2005/09/implandental.html. Accesed October 10.

16. Priaminiarti M. Prosedur operasional baku pemeriksaan radiografik pada perawatan implan gigi. Jakarta: Departemen Radiologi Kedokteran Gigi Fakultas Kedokteran Gigi Universitas Indonesia; 2008. hal. 1-14.

17. Adell R. Long-term treatment results. In: Branemark P-1, Zarb GA, Albrektsson T, editors. Tissue-integreted protheses osseointegration in clinical dentistry. Chicago: Quintessence Publishing Co; 1985. p.175-86.

18. James R, Altman A, Clem D, Alozada J. Critical review of the osseointegreted literature. Int J Oral implantol 1986; 3(3): 3541.

19. Kucey BKS. Implant placement in prosthodontics practice: a five-year retrospective study. J Prosthet Dent 1997; 7: 171-6.

20. Gaucher H. Bentley K, Roy S, Head T, Blomfield J, Blondeau F, et al. A Multi-centre study of osseotite implants supporting mandibular restoration: A 3-year report. J Can Dent Assoc 2001; 67(9): 528-83.

21. Mason R. A guide to dental radiography. Bristol: John Wright and Sons Limited; 1997. p. 20-35.

22. Eselmen JCWJ, Updegrave, Archer WH. Panoramic radiographs and localization. Oral Maxillofacial surgery, Vol $15^{\text {th }}$ ed. Philadelphia: WB Saunders Co; 1975. p.9821011.

23. Gibiliso JA, Turlington EG., Del Van Grevenhof. Radiography techniques. Stafne's oral radiographic diagnosis. $5^{\text {th }}$ ed. Philadelphia: WB Saunders Co.; 1985: 41043.

24. Informasi diagnostik maksimal dari radiografi. Available from: http://www.pdgi.online.com. Diakses tanggal 3 Desember 2008.

25. De Lyre WR, Johnson ON. Essential of dental radiography for dental assistants and hygienist, $4^{\text {th }}$ ed. Connecticut: Appleton \& Lange; 1990. p.319-28. 